\title{
Effect of $\mathrm{CO}_{2}$ Enrichment on Growth and Flowering of Phalaenopsis
}

\author{
Hyun Jin Kim¹, Ah Ram Cho' ${ }^{1}$ Kyoung Sub Park ${ }^{2}$ and Yoon Jin Kim ${ }^{1 *}$ \\ ${ }^{1}$ Department of Horticulture, Biotechnology and Landscape Architecture, Seoul Women's University, Seoul 01797, Korea \\ ${ }^{2}$ Protected Horticulture Research Institute, National Institute of Horticultural \& Herbal Science, Gyeongsangnam-do 52035, \\ Korea
}

To increase the photosynthesis of crop and improve plant quality, we evaluated the effect of elevated $\mathrm{CO}_{2}$ on vegetative growth and flowering in Phalaenopsis 'Fuller's Pink Swallow'. Plants were exposed to 450 (control), 800,1600 , and $2400 \mu \mathrm{mol} \cdot \mathrm{mol}^{-1} \mathrm{CO}_{2}$ for 31 weeks. The number of leaves, leaf length, and leaf width displayed greater increases in plants grown under 1600 and $2400 \mu \mathrm{mol} \cdot \mathrm{mol}^{-1} \mathrm{CO}_{2}$ than in plants grown under 450 and $800 \mu \mathrm{mol} \cdot \mathrm{mol}^{-1} \mathrm{CO}_{2}$. The times to leaf initiation were reduced to 90.7 and 85.8 days in plants grown under 1600 and $2400 \mu \mathrm{mol} \cdot \mathrm{mol}^{-1} \mathrm{CO}_{2}$, respectively, compared with that of the control, 177.1 days. The leaf elongation rate was significantly increased in plants grown under 1600 and $2400 \mu \mathrm{mol} \cdot \mathrm{mol}^{-1} \mathrm{CO}_{2}$ compared to plants grown under 450 and $800 \mu \mathrm{mol} \cdot \mathrm{mol}^{-1} \mathrm{CO}_{2}$. Plants grown under $1600 \mu \mathrm{mol} \cdot \mathrm{mol}^{-1} \mathrm{CO}_{2}$ had the highest total number of flower buds among all plants grown under the four tested $\mathrm{CO}_{2}$ concentrations. Leaf injuries were not observed in any plants regardless of $\mathrm{CO}_{2}$ concentration, but flower bud abortion and bud withering were observed in $\mathrm{CO}_{2}$-enriched plants, especially in plants grown under 1600 and $2400 \mu \mathrm{mol} \cdot \mathrm{mol}^{-1} \mathrm{CO}_{2}$. Plants subjected to long-term $\mathrm{CO}_{2}$ elevation of over $800 \mu \mathrm{mol} \cdot \mathrm{mol}^{-1}$ displayed increased biomass production despite a concomitant reduction in the number of buds. These results showed that 1600 and $2400 \mu \mathrm{mol} \cdot \mathrm{mol}^{-1} \mathrm{CO}_{2}$ significantly enhanced the vegetative growth of Phalaenopsis. However, long-term exposure to high $\mathrm{CO}_{2}$ concentrations can adversely affect the flowering of Phalaenopsis, and result in reduced flower production and increased flower bud abortion.

Key Words: CAM plants, $\mathrm{CO}_{2}$ concentration, flowering quality, long-term $\mathrm{CO}_{2}$ treatment, withered flower buds.

\section{Introduction}

Atmospheric $\mathrm{CO}_{2}$ is rising at an unprecedented rate, and the upward trend is mostly linked to anthropogenic emissions. To reduce $\mathrm{CO}_{2}$ emissions, stabilization of the atmospheric $\mathrm{CO}_{2}$ concentration a combination of limiting fossil fuel use and creation of carbon sinks, especially crassulacean acid metabolism (CAM) plants, could be exploited for terrestrial sequestration of atmospheric $\mathrm{CO}_{2}$ (Reddy et al., 2010). This has promoted considerable interest in the potential impact of elevated $\mathrm{CO}_{2}$ on plant production systems. $\mathrm{CO}_{2}$ enrichment ben-

Received; June 16, 2016. Accepted; September 30, 2016.

First Published Online in J-STAGE on November 11, 2016.

This Work was supported by the ICT R\&D Program of MSIP (R0236-15-1007, Development of Future Integrated Smart Energy System for Agricultural Greenhouses) of the Creative Vitamin Project and by "Cooperative Research Program for Agriculture Science \& Technology Development (Project No. PJ012069)" Rural Development Administration, Republic of Korea.

* Corresponding author (E-mail: yj1082@swu.ac.kr). efits ornamental plant production by stimulating plant growth, which in turn improves flower yield and quality (Liu et al., 2000). A $\mathrm{CO}_{2}$ concentration from 700 to $900 \mathrm{ppm}$ is generally recommended in greenhouses (Mortensen, 1987). However, the amount of $\mathrm{CO}_{2}$ a plant requires for optimum growth varies from plant to plant (Gouk et al., 1997; Mortensen, 1987). For example, an early report on the effect of $\mathrm{CO}_{2}$ concentrations on the growth of the 'Hark' soybean reported that higher seed yield was obtained by treatment with $1350 \mathrm{ppm}$ $\mathrm{CO}_{2}$ (Cooper and Brun, 1967). Without visible morphological damage, the stem and leaf growth rate were increased in Pharbitis nil Choisy grown under $5000 \mathrm{ppm}$ $\mathrm{CO}_{2}$ (Hicklenton and Jolliffe, 1980). Optimal $\mathrm{CO}_{2}$ concentrations for plant growth and flower production were $900 \mathrm{ppm}$ in Alstroemeria 'Fiona', whereas the flower quality in Alstroemeria 'Helios' decreased significantly at $900 \mathrm{ppm} \mathrm{CO}_{2}$ (Van Labeke and Dambre, 1998). Therefore, optimizing the $\mathrm{CO}_{2}$ concentration is required to improve plant growth and quality based on plant species and genotypes. 
Phalaenopsis holds a leading position in the number of potted plants sold internationally. Phalaenopsis plants with multiple spikes and more flowers yield higher prices; therefore, Phalaenopsis growers look for ways to increase the number of spikes and flowers. Phalaenopsis is a CAM plant, which fixes $\mathrm{CO}_{2}$ during the daily scotoperiod (Guo and Lee, 2006). Unlike $\mathrm{C}_{3}$ and $\mathrm{C}_{4}$ plants, studies investigating the effects of $\mathrm{CO}_{2}$ enrichment on the vegetative and reproductive growth of CAM plants have reported inconsistent outcomes, including decreases in vegetative growth, no change in either vegetative growth or $\mathrm{CO}_{2}$ uptake (Croonenborghs et al., 2009), and large increases in both vegetative growth and $\mathrm{CO}_{2}$ uptake (Monteiro et al., 2009; Weiss et al., 2010).

A previous study reported that up to $1000 \mathrm{ppm} \mathrm{CO}_{2}$ may have a positive effect on photosynthesis and flowering in Phalaenopsis (Kromwijk et al., 2014). Endo and Ikushima (1997) observed increases in the number of spikes and flowers, and higher spike fresh weight in cut flower Phalaenopsis when the $\mathrm{CO}_{2}$ concentration was increased to 700 and $1000 \mathrm{ppm}$. Hwang and Jeong (2009) suggested that the vegetative growth of Phalaenopsis cultivars grown under $2000 \mathrm{ppm} \mathrm{CO}_{2}$ was greater than that of plants grown under $1000 \mathrm{ppm} \mathrm{CO}_{2}$. Previous studies were unable to evaluate the effects of long-term $\mathrm{CO}_{2}$ enrichment on both vegetative and flowering response in Phalaenopsis. $\mathrm{CO}_{2}$ concentration is a key environmental factor influencing the metabolism and development of CAM plants; therefore, further improvement in Phalaenopsis production demands a better understanding of plant responses to $\mathrm{CO}_{2}$. The objective of this study was to determine the optimum $\mathrm{CO}_{2}$ concentration to improve the growth and flowering quality of Phalaenopsis 'Fuller's Pink Swallow'.

\section{Materials and Methods}

\section{Plant growth conditions}

Phalaenopsis 'Fuller's Pink Swallow' was propagated by tissue culture, and 15-month-old clones were purchased from Gobong Orchid Nursery, Goyang, Korea (latitude $\quad 37^{\circ} 43^{\prime} 38.2^{\prime \prime} \mathrm{N}, \quad$ longitude $\left.126^{\circ} 49^{\prime} 49.6^{\prime \prime E}\right)$. Plants with six leaves $(5.3 \mathrm{~cm}$ in diameter and $11.5 \mathrm{~cm}$ in length) were transplanted into $12 \mathrm{~cm}$ pots filled with $65 \%$ peat moss (Klasmann-Dellmann GmbH, Geeste, Germany), 30\% sphagnum moss (Lonquen Ltd., Puerto Montt, Chile), and 5\% Indonesian medium-grade Douglas fir bark. Twenty plants each were cultured in four different growth chambers (HB-301MP; Hanbaek Scientific Co., Ansan, Korea; $1.4 \mathrm{~m} \times 1.1 \mathrm{~m} \times 2.1 \mathrm{~m}$ ) with different $\mathrm{CO}_{2}$ concentrations. The air temperatures of the cultivation periods for vegetative growth, flower spike induction, and flower spike development were 29/29, 23/18, and $25 / 20^{\circ} \mathrm{C}$ ( $12 \mathrm{~h} \mathrm{light} / 12 \mathrm{~h}$ dark), respectively. The daytime photosynthetic photon flux density of the cultivation periods for vegetative growth, flower spike induction, and flower spike development were 120, 160 , and $160 \mu \mathrm{mol} \cdot \mathrm{m}^{-2} \cdot \mathrm{s}^{-1}$ from 12:00 to 24:00, respectively. Photosynthetic photon flux was provided at the plant canopy with three-wave cool white fluorescent lamps (Triband phosphor fluorescent lamp, Dulux L 36 W; Osram Korea Co., Korea). The relative humidity in the growth chamber was $50 \%$ during the experimental period. The plants were fertigated once every 10 days by hand with a solution of water-soluble fertilizer (EC $0.8 \pm 0.1 \mathrm{dS} \cdot \mathrm{cm}^{-1}$ and pH 6.0-6.5; Newgold 20N-8.7P-16.7K; Neufarm Corp., Ltd., Munster, Germany).

\section{$\mathrm{CO}_{2}$ enrichment}

Twenty plants each were cultured in four different growth chambers with different $\mathrm{CO}_{2}$ concentrations (daily mean of ambient atmosphere $450 \mu \mathrm{mol} \cdot \mathrm{mol}^{-1}$ ), 800,1600 , and $2400 \mu \mathrm{mol} \cdot \mathrm{mol}^{-1}$. The $\mathrm{CO}_{2}$ concentration was maintained by automated continuous injection of pure $\mathrm{CO}_{2}$. Pure $\mathrm{CO}_{2}$ (cylinders of compressed $\mathrm{CO}_{2}$; Seoul Gases Co., Ltd., Seoul, Korea) was supplied through a flow meter that controlled the flow rate at approximately $50 \mathrm{~mL} \cdot \mathrm{min}^{-1}$. In all four chambers, the $\mathrm{CO}_{2}$ concentrations were monitored by using a $\mathrm{CO}_{2}$ analyzer (AM-21A; WISE Sensing Inc., Gyeonggi, Korea). $\mathrm{CO}_{2}$ treatments were applied to the plants for 6 hours during the nighttime (18:00-24:00) in a controlled growth chamber for 31 weeks.

\section{Growth and flowering parameters}

The total number of leaves with lengths of $\geq 0.5 \mathrm{~cm}$ was measured for each plant every 2 weeks for 31 weeks. Leaf length and width were measured every 2 weeks for each plant, starting with the first leaf that was produced after the start of $\mathrm{CO}_{2}$ treatment. The leaf elongation rate (LER) was calculated from the equation: $\mathrm{LER}=d L / d t$ ( $L$, leaf length; $t$, days after treatment). The time to leaf initiation from the start of $\mathrm{CO}_{2}$ treatment was measured when the first visible leaf was $0.5 \mathrm{~cm}$ long. The leaf chlorophyll content was measured in the uppermost mature leaf using a chlorophyll meter (SPAD 502; Konica Minolta Sensing, Inc., Sakai, Japan) at 31 weeks after the start of the treatment. The fresh and dry weight of shoots and roots were measured at 31 weeks after the start of $\mathrm{CO}_{2}$ treatment. Dry weight was measured after drying the shoots and roots in an oven at $80^{\circ} \mathrm{C}$ for 10 days.

Flowering was defined as full expansion of the labellum of the first flower. Days to flowering were recorded. The flowering percentage was calculated as the percentage of flowering plants out of twelve plants. The number of flower spikes and flowers was counted for each plant once a week. At flowering, the flower spike length was measured for the first flower spike. Lateral branch length, total number of buds, and total number of withered buds was measured for each plant every 2 weeks. The fresh weight of flower spikes was measured 
first, then the flower spikes were dried in an oven at $80^{\circ} \mathrm{C}$ for 10 days and dry weight was measured.

\section{Statistical analysis}

The experimental design was a completely randomized block with twelve replicates of one plant each. Statistical analyses were performed using the SAS system (version 9.3; SAS Institute Inc., Cary, NC, USA). Mean separation was performed on all other data with Tukey's honestly significant difference test at $P<0.05$. Graph module analysis was performed using Sigma Plot software (version 10.0; Systat Software Inc., Chicago, IL, USA).

\section{Results}

\section{Leaf growth and development}

Phalaenopsis plants grown under 1600 and $2400 \mu \mathrm{mol} \cdot \mathrm{mol}^{-1} \mathrm{CO}_{2}$ produced more leaves than those grown under 450 and $800 \mu \mathrm{mol} \cdot \mathrm{mol}^{-1} \mathrm{CO}_{2}$ at 17 weeks after the start of treatment (Fig. 1A). Leaf length and width were significantly greater in plants grown under 1600 and $2400 \mu \mathrm{mol} \cdot \mathrm{mol}^{-1} \mathrm{CO}_{2}$ than in plants grown under 450 and $800 \mu \mathrm{mol} \cdot \mathrm{mol}^{-1} \mathrm{CO}_{2}$ at 16 weeks after the start of the treatment (Fig. 1B and C). The time to leaf initiation was reduced to 90.7 and 85.8 days in plants grown under 1600 and $2400 \mu \mathrm{mol} \cdot \mathrm{mol}^{-1} \mathrm{CO}_{2}$, respectively, compared with that of the control's 177.1 days (Table 1). The leaf elongation rate was significantly increased in plants grown under 1600 and $2400 \mu \mathrm{mol} \cdot \mathrm{mol}^{-1} \mathrm{CO}_{2}$ compared to plants grown under 450 and $800 \mu \mathrm{mol} \cdot \mathrm{mol}^{-1} \mathrm{CO}_{2}$. The fresh weight of roots was higher for plants grown under 800,1600, and $2400 \mu \mathrm{mol} \cdot \mathrm{mol}^{-1} \mathrm{CO}_{2}$ than for plants grown under $450 \mu \mathrm{mol} \cdot \mathrm{mol}^{-1} \mathrm{CO}_{2}$, but there were no significant differences in the leaf chlorophyll content, and the fresh and dry weight of shoots for plants grown under the four tested $\mathrm{CO}_{2}$ concentrations (Table 1).

\section{Flowering/inflorescence characteristics}

Days to flowering of plants grown under $800 \mu \mathrm{mol} \cdot \mathrm{mol}^{-1} \mathrm{CO}_{2}$ was delayed for about 33 days compared to the 170 days of plants grown under $450 \mu \mathrm{mol} \cdot \mathrm{mol}^{-1} \quad \mathrm{CO}_{2}$ (Table 2). Approximately $92 \%$ and $67 \%$ of plants grown under 450 and $800 \mu \mathrm{mol} \cdot \mathrm{mol}^{-1} \mathrm{CO}_{2}$ flowered, respectively. In contrast,

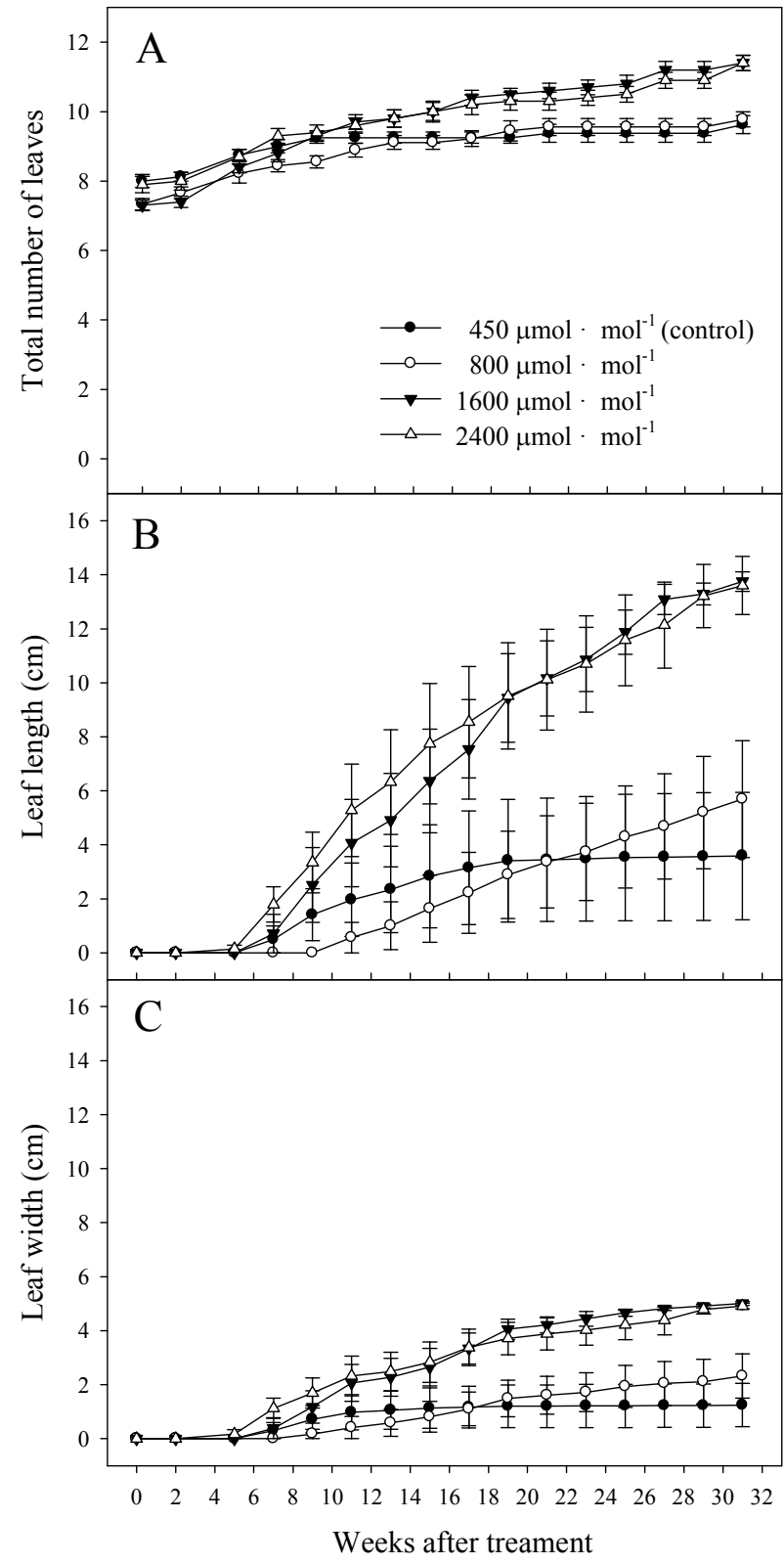

Fig. 1. Changes in total number of leaves (A), leaf length (B), and leaf width (C) of Phalaenopsis 'Fuller's Pink Swallow' under different $\mathrm{CO}_{2}$ concentrations. Error bars represent means $\pm \mathrm{SE}$, $\mathrm{n}=12$.

Table 1. Effects of $\mathrm{CO}_{2}$ concentration on time to leaf initiation, leaf elongation rate, leaf chlorophyll content, and fresh and dry weight of shoots and roots in Phalaenopsis 'Fuller's Pink Swallow' after 31 weeks.

\begin{tabular}{|c|c|c|c|c|c|c|c|}
\hline \multirow{2}{*}{$\begin{array}{c}\mathrm{CO}_{2} \text { concentration } \\
\left(\mu \mathrm{mol} \cdot \mathrm{mol}^{-1}\right)\end{array}$} & \multirow{2}{*}{$\begin{array}{l}\text { Time to leaf } \\
\text { initiation (days) }\end{array}$} & \multirow{2}{*}{$\begin{array}{l}\text { Leaf elongation } \\
\text { rate }\left(\mathrm{cm} \cdot \text { day }^{-1}\right)\end{array}$} & \multirow{2}{*}{$\begin{array}{l}\text { Leaf chlorophyll } \\
\text { content (SPAD) }\end{array}$} & \multicolumn{2}{|c|}{ Fresh weight (g) } & \multicolumn{2}{|c|}{ Dry weight (g) } \\
\hline & & & & Shoots & Roots & Shoots & Roots \\
\hline 450 (control) & $177.1 \mathrm{a}^{\mathrm{z}}$ & $0.019 \mathrm{c}$ & $73.93 \mathrm{a}$ & $55.05 \mathrm{a}$ & $17.0 \mathrm{~b}$ & $3.636 \mathrm{a}$ & $1.92 \mathrm{~b}$ \\
\hline 800 & $163.4 \mathrm{ab}$ & $0.030 \mathrm{bc}$ & $73.67 \mathrm{a}$ & $55.02 \mathrm{a}$ & $21.5 \mathrm{a}$ & $3.555 \mathrm{a}$ & $1.96 \mathrm{a}$ \\
\hline 1600 & $86.4 \mathrm{c}$ & $0.053 \mathrm{ab}$ & $71.39 \mathrm{a}$ & $56.93 \mathrm{a}$ & $21.2 \mathrm{a}$ & $3.482 \mathrm{a}$ & $2.05 \mathrm{a}$ \\
\hline 2400 & $91.3 \mathrm{bc}$ & $0.061 \mathrm{a}$ & $73.95 \mathrm{a}$ & $54.90 \mathrm{a}$ & $22.3 \mathrm{a}$ & $3.470 \mathrm{a}$ & $2.22 \mathrm{a}$ \\
\hline
\end{tabular}

${ }^{\mathrm{z}}$ Mean separation within columns by Tukey's honestly significant difference test at $P<0.05(\mathrm{n}=12)$. 
none of the plants grown under 1600 and $2400 \mu \mathrm{mol} \cdot \mathrm{mol}^{-1} \mathrm{CO}_{2}$ flowered during the experiment due to aberrant flower development and bud drop (Table 2; Fig. 2D). The number of flower spikes was not significantly affected by different $\mathrm{CO}_{2}$ concentrations. The number of flowers was significantly higher in plants grown under $450 \mu \mathrm{mol} \cdot \mathrm{mol}^{-1} \mathrm{CO}_{2}$ than in plants grown under $800 \mu \mathrm{mol} \cdot \mathrm{mol}^{-1} \mathrm{CO}_{2}$. The fresh and dry weights of flower spikes were highest in plants grown under $450 \mu \mathrm{mol} \cdot \mathrm{mol}^{-1} \mathrm{CO}_{2}$ compared with those under the other $\mathrm{CO}_{2}$ concentrations. Plants grown under $2400 \mu \mathrm{mol} \cdot \mathrm{mol}^{-1} \mathrm{CO}_{2}$ produced longer flower spikes than plants grown under the other tested $\mathrm{CO}_{2}$ concentra- tions at 26 weeks after the start of treatment (Fig. 2A). All plants produced lateral branches at 18 weeks after the start of the treatment. The lateral branch length was significantly longer in plants grown under $2400 \mu \mathrm{mol} \cdot \mathrm{mol}^{-1} \mathrm{CO}_{2}$ than under the other $\mathrm{CO}_{2}$ concentrations at 23 weeks after the start of treatment (Fig. 2B). Floral buds appeared at 17 weeks after the start of treatment regardless of $\mathrm{CO}_{2}$ concentration (Fig. 2C). Plants grown under $1600 \mu \mathrm{mol} \cdot \mathrm{mol}^{-1} \mathrm{CO}_{2}$ had the highest total number of flower buds compared with plants grown under the other $\mathrm{CO}_{2}$ concentrations. However, flower buds became withered in plants grown under 1600 and $2400 \mu \mathrm{mol} \cdot \mathrm{mol}^{-1} \mathrm{CO}_{2}$ at 20 weeks after

Table 2. Effects of $\mathrm{CO}_{2}$ concentration on days to flowering, flowering percentage, number of flower spikes and flowers, and fresh and dry weight of flower spikes in Phalaenopsis 'Fuller's Pink Swallow' after 31 weeks.

\begin{tabular}{ccccccc}
\hline \hline $\begin{array}{c}\mathrm{CO}_{2} \text { concentration } \\
\left(\mu \mathrm{mol} \cdot \mathrm{mol}^{-1}\right)\end{array}$ & $\begin{array}{c}\text { Days to } \\
\text { flowering }\end{array}$ & $\begin{array}{c}\text { Flowering } \\
\text { Percentage }\end{array}$ & $\begin{array}{c}\text { Number of } \\
\text { flower spikes }\end{array}$ & $\begin{array}{c}\text { Number of } \\
\text { flowers }\end{array}$ & $\begin{array}{c}\text { Fresh weight }^{\mathrm{z}} \\
(\mathrm{g})\end{array}$ & $\begin{array}{c}\text { Dry weight }^{\mathrm{z}} \\
(\mathrm{g})\end{array}$ \\
\hline $450($ control $)$ & $170 \mathrm{~b}^{\mathrm{y}}$ & 92 & $1.87 \mathrm{a}$ & $9.1 \mathrm{a}$ & $22.4 \mathrm{a}$ & $2.09 \mathrm{a}$ \\
800 & $203 \mathrm{a}$ & 67 & $1.50 \mathrm{a}$ & $5.5 \mathrm{~b}$ & $15.3 \mathrm{~b}$ & $1.38 \mathrm{~b}$ \\
1600 & $-{ }^{\mathrm{x}}$ & 0 & $2.25 \mathrm{a}$ & $0.0 \mathrm{c}$ & $11.7 \mathrm{bc}$ & $1.39 \mathrm{~b}$ \\
2400 & - & 0 & $1.67 \mathrm{a}$ & $0.0 \mathrm{c}$ & $10.8 \mathrm{c}$ & $1.23 \mathrm{~b}$ \\
\hline
\end{tabular}

${ }^{\mathrm{z}}$ Fresh and dry weight of flower spikes includes flowers and buds.

y Mean separation within columns by Tukey's honestly significant difference test at $P<0.05(\mathrm{n}=12)$.

${ }^{\mathrm{x}}$ The dash symbol (-) indicates that no information was available at 31 weeks.

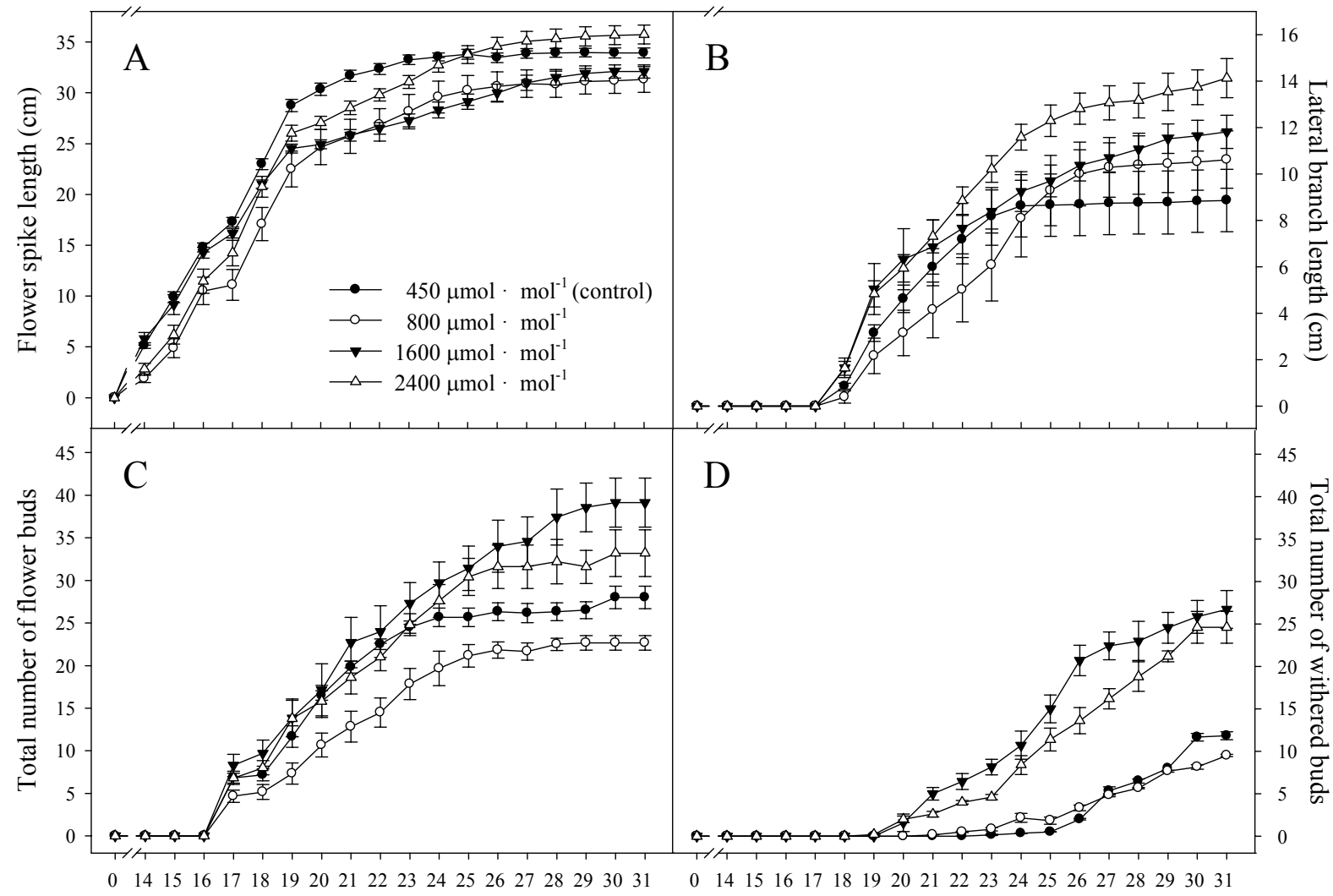

Weeks after treatment

Fig. 2. Changes in the flower spike length (A), lateral branch length (B), total number of flower buds (C), and total number of withered buds (D) of Phalaenopsis 'Fuller's Pink Swallow' under different $\mathrm{CO}_{2}$ concentrations. Error bars represent means $\pm \mathrm{SE}, \mathrm{n}=12$. 
the start of treatment, and the total number of withered buds sharply increased at 23 weeks (Fig. 2D). The flower buds in plants grown under 1600 and $2400 \mu \mathrm{mol} \cdot \mathrm{mol}^{-1} \mathrm{CO}_{2}$ finally dropped after the experiment ended (data not shown).

\section{Discussion}

This study showed that $\mathrm{CO}_{2}$ enrichment significantly increased leaf development, which was measured as the number of leaves, leaf length, and leaf width (Fig. 1). Leaf growth rates are frequently modulated by differences in plant water potential (Taylor et al., 1994). Leaf growth under elevated $\mathrm{CO}_{2}$ concentration enhances the efficiency of water use, which increases cell turgor pressure, promotes cell wall relaxation and/or cell division (Pritchard et al., 1999), and thereby increases the leaf elongation rate (Table 1). Lateral branch length and flower spike length of Phalaenopsis 'Fuller's Pink Swallow' increased especially in plants grown under 1600 and $2400 \mu \mathrm{mol} \cdot \mathrm{mol}^{-1} \mathrm{CO}_{2}$. Numerous studies have reported increased stem or branch elongation in plants grown under elevated $\mathrm{CO}_{2}$. For example, Rogers et al. (1992) reported a 15\% increase in plant height for Glycine max grown under elevated $\mathrm{CO}_{2}$. Similarly, the height of Triticum aestivum plants grown under elevated $\mathrm{CO}_{2}$ increased by $17 \%$ due to increased internode length rather than increases in the numbers of nodes (Slafer and Rawson, 1997). Increases in the numbers of branches with elevated $\mathrm{CO}_{2}$ can be due to effects on overall developmental rate rather than changes in the pattern of branch initiation (Ackerly et al., 1992). In the present study, the flower spike number did not significantly differ among the treatments. These results suggest that $\mathrm{CO}_{2}$ enrichment stimulates the growth and development of cells and tissues below the site of lateral organ formation to a greater extent than it stimulates organ primordia formation at the shoot tip (Pritchard et al., 1999).

Plant quality, expressed by the growth habit and the number of flowers, is often enhanced by $\mathrm{CO}_{2}$ enrichment (Endo and Ikushima, 1997). $\mathrm{CO}_{2}$ application can increase growth rates and reduce production time, but leaf senescence or visible leaf injuries such as chlorosis, necrosis, and leaf curling is observed at higher $\mathrm{CO}_{2}$ levels in some annual plants (Mortensen, 1987). In ornamental bromeliads, $\mathrm{CO}_{2}$ enrichment induced aberrant plant shapes with long and slender leaves (Croonenborghs et al., 2009). In the present study, visible leaf injuries were not observed in any plants regardless of $\mathrm{CO}_{2}$ concentration, but withered flower buds and bud abortion were observed in $\mathrm{CO}_{2}$-enriched plants, especially in plants grown under $\geq 1600 \mu \mathrm{mol} \cdot \mathrm{mol}^{-1} \mathrm{CO}_{2}$, resulting in non-flowering (Fig. 2D; Table 2). The ability of plants to respond to elevated $\mathrm{CO}_{2}$ levels depends on physiological characteristics such as sink strength, efficiency of nitrogen and water use, and photosynthetic pathway and capacity (Diaz, 1995; Pritchard et al.,
1999). If plants are unable to use fixed carbon for growth, the result is typically an increase in total nonstructural carbohydrates and possibly increased levels of carbon-based secondary compounds (Poorter et al., 1997). However, limitations on carbon assimilation may be imposed by mechanical and biochemical processes within source leaves resulting from weak sink activity (Pritchard et al., 1999). Other structural functional attributes may limit the capacity to exploit the extra carbon available under higher $\mathrm{CO}_{2}$ concentrations. Temporal competition for carbohydrates appeared between vegetative and reproductive organs. The sucrose synthesis in the developing shoot tips of peaches reached the maximum when growth in fruits was lowest (Lo Bianco et al., 1999). In maize, ovary abortion under stress conditions is often a consequence of carbon starvation rather than a direct effect of these stresses (Mäkelä et al., 2005). In this study, the leaf elongation rate increased by $\mathrm{CO}_{2}$ enrichment (Table 1), whereas flower buds dropped in plants grown under over $1600 \mu \mathrm{mol} \cdot \mathrm{mol}^{-1} \mathrm{CO}_{2}$ (Fig. 2D). This may be related to the changed sink strength or carbon limitation between leaves and flower buds under higher $\mathrm{CO}_{2}$ concentrations.

In many cases, plant growth responses to elevated $\mathrm{CO}_{2}$ may be modulated by nutrient availability (Conroy et al., 1990; Prior et al., 1997) or supplemental light. For example, restricting the nutrient concentration to a low level of $1.0 \mathrm{mS} \cdot \mathrm{cm}^{-1}$ blocked the effect of $\mathrm{CO}_{2}$ enrichment on growth due to nutrient deficiency, whereas $\mathrm{CO}_{2}$ enrichment with a high nutrient concentration of $4.0 \mathrm{mS} \cdot \mathrm{cm}^{-1}$ increased growth and enhanced plant quality (Meier and Fuhrer, 1997). In Alstroemeria, the combined effect of $\mathrm{CO}_{2}$ enrichment and supplemental lighting enhanced flower stem growth and prevented flower abortion more significantly than that of either factor alone (Van Labeke and Dambre, 1993). These results suggest that complex environmental conditions should be considered when plants are grown under $\mathrm{CO}_{2}$-enriched air in order to maintain high plant quality. Further study on the effects of $\mathrm{CO}_{2}$ interaction with other environmental factors is required for Phalaenopsis cultivation.

In conclusion, this study showed that 1600 and $2400 \mu \mathrm{mol} \cdot \mathrm{mol}^{-1} \mathrm{CO}_{2}$ significantly enhanced vegetative growth of Phalaenopsis. However, long-term exposure to high $\mathrm{CO}_{2}$ concentrations can adversely affect the flowering of Phalaenopsis, and result in reduced flower production and increased flower bud abortion. Phalaenopsis subjected to $\mathrm{CO}_{2}$-enriched conditions of over $800 \mu \mathrm{mol} \cdot \mathrm{mol}^{-1} \mathrm{CO}_{2}$ before flower spike induction displayed increased biomass production.

\section{Literature Cited}

Ackerly, D. D., J. S. Coleman, S. R. Morse and F. A. Bazzaz. 1992. $\mathrm{CO}_{2}$ and temperature effects on leaf area production in two annual plant species. Ecology 73: 1260-1269. 
Conroy, J. P., P. J. Milham, M. L. Reed and E. W. Barlow. 1990. Increases in phosphorus requirements for $\mathrm{CO}_{2}$-enriched pine species. Plant Physiol. 92: 977-982.

Cooper, R. L. and W. A. Brun. 1967. Response of soybeans to a carbon dioxide-enriched atmosphere. Crop Sci. 7: 455-457.

Croonenborghs, S., J. Ceusters, E. Londers and M. P. De Proft. 2009. Effects of elevated $\mathrm{CO}_{2}$ on growth and morphological characteristics of ornamental bromeliads. Sci. Hortic. 121: 192-198.

Diaz, S. 1995. Elevated $\mathrm{CO}_{2}$ responsiveness, interactions at the community level and plant functional types. J. Biogeogr. 22: 289-295.

Endo, M. and I. Ikushima. 1997. Effect of $\mathrm{CO}_{2}$ enrichment on yield and preservability of cut flowers in Phalaenopsis. J. Japan. Soc. Hort. Sci. 66: 169-174.

Gouk, S. S., J. W. H. Yong and C. S. Hew. 1997. Effects of superelevated $\mathrm{CO}_{2}$ on the growth and carboxylating enzymes in an epiphytic CAM orchid plantlet. J. Plant Physiol. 151: 129-136.

Guo, W. J. and N. Lee. 2006. Effect of leaf and plant age, and day/night temperature on net $\mathrm{CO}_{2}$ uptake in Phalaenopsis amabilis var. formosa. J. Amer. Soc. Hort. Sci. 131: 320326.

Hicklenton, P. R. and P. A. Jolliffe. 1980. Carbon dioxide and flowering in Pharbitis nil Choisy. Plant Physiol. 66: 13-17.

Hwang, S. J. and B. R. Jeong. 2009. Effect of $\mathrm{CO}_{2}$ concentration and fertilization time on the growth of potted Phalaenopsis. Flower Res. J. 17: 29-35.

Kromwijk, J. A. M., E. Meinen and T. A. Dueck. 2014. The effect of elevated $\mathrm{CO}_{2}$ on the vegetative and generative growth of Phalaenopsis. Acta Hortic. 1025: 155-161.

Liu, G., R. D. Heins, A. C. Cameron and W. H. Carlson. 2000. Day and night temperatures, daily light integral, and $\mathrm{CO}_{2}$ enrichment affect growth and flower development of pansy $($ Viola $\times$ wittrochiana $)$. J. Amer. Soc. Hort. Sci. 125: 436441.

Lo Bianco, R., M. Rieger and S. S. Sung. 1999. Carbohydrate metabolism of vegetative and reproductive sinks in the latematuring peach cultivar 'Encore'. Tree Physiol. 19: 103109.

Mäkelä, P., J. E. Mclaughlin and J. S. Boyer. 2005. Imaging and quantifying carbohydrate transport to the developing ovaries of maize. Ann. Bot. 96: 939-949.
Meier, M. and J. Fuhrer. 1997. Effect of elevated $\mathrm{CO}_{2}$ on orchard grass and red clover grown in mixture at two levels of nitrogen or water supply. Environ. Exp. Bot. 38: 251-262.

Monteiro, J. A. F., G. Zotz and C. Körner. 2009. Tropical epiphytes in a $\mathrm{CO}_{2}$-rich atmosphere. Acta Oecol. 35: 60-68.

Mortensen, L. M. 1987. Review: $\mathrm{CO}_{2}$ enrichment in greenhouse. Crop responses. Sci. Hortic. 33: 1-25.

Poorter, H., Y. Van Berkel, R. Baxter, J. Den Hertog, P. Dijkstra, R. M. Gifford, K. L. Griffin, C. Roumet, J. Roy and S. C. Wong. 1997. The effect of elevated $\mathrm{CO}_{2}$ on the chemical composition and construction costs of leaves of $27 \mathrm{C}_{3}$ species. Plant Cell Environ. 20: 472-482.

Prior, S. A., G. B. Runion, R. J. Mitchell, H. H. Rogers and J. S. Amthor. 1997. Effects of atmospheric $\mathrm{CO}_{2}$ on longleaf pine: productivity and allocation as influenced by nitrogen and water. Tree Physiol. 17: 397-405.

Pritchard, S., H. Rogers, S. A. Prior and C. Peterson. 1999. Elevated $\mathrm{CO}_{2}$ and plant structure: a review. Global Change Biol. 5: 807-837.

Reddy, A. R., G. K. Rasineni and A. S. Raghavendra. 2010. The impact of global elevated $\mathrm{CO}_{2}$ concentration on photosynthesis and plant productivity. Curr. Sci. 99: 46-57.

Rogers, H. H., C. M. Peterson, J. N. McCrimmon and J. D. Cure. 1992. Response of plant roots to elevated atmospheric carbon dioxide. Plant Cell Environ. 15: 749-752.

Slafer, G. A. and H. M. Rawson. 1997. $\mathrm{CO}_{2}$ effects on phasic development, leaf number and rate of leaf appearance in wheat. Ann. Bot. 79: 75-81.

Taylor, G., S. Ranasinghe, C. Bosac, S. D. L. Gardner and R. Ferris. 1994. Elevated $\mathrm{CO}_{2}$ and plant growth: cellular mechanisms and responses of whole plants. J. Exp. Bot. 45: 1761-1774.

Van Labeke, M. C. and P. Dambre. 1993. Response of five Alstroemeria cultivars to soil cooling and supplementary lighting. Sci. Hortic. 56: 135-145.

Van Labeke, M. C. and P. Dambre. 1998. Effects of supplementary lighting and $\mathrm{CO}_{2}$ enrichment on yield and flower stem quality of Alstroemeria cultivars. Sci. Hortic. 74: 269-278.

Weiss, I., Y. Mizrahi and E. Raveh. 2010. Effect of elevated $\mathrm{CO}_{2}$ on vegetative and reproductive growth characteristics of the CAM plants Hylocereus undatus and Selenicereus megalanthus. Sci. Hortic. 123: 531-536. 